\title{
Validation of a Cell-Based Assay for Detection of Active Shiga Toxins Produced by Escherichia coli in Water
}

\author{
Anna C. Hughes ${ }^{1}$, Stephanie Patfield ${ }^{1,2}{ }^{-}$, Reuven Rasooly ${ }^{1}$ and Xiaohua He ${ }^{1, *}$ \\ 1 Western Regional Research Center, United States Department of Agriculture, Agricultural Research Service, \\ 800 Buchanan St., Albany, CA 94710, USA; anna.hughes@usda.gov (A.C.H.); steph@patfield.com (S.P.); \\ reuven.rasooly@usda.gov (R.R.) \\ 2 Forensic Services Division, Contra Costa County Office of the Sheriff, 651 Pine St., Martinez, CA 94553, USA \\ * Correspondence: xiaohua.he@usda.gov; Tel.: +1-(510)-559-5823
}

Received: 3 October 2020; Accepted: 20 October 2020; Published: 28 October 2020

\begin{abstract}
Shiga toxin-producing Escherichia coli (STEC) causes a wide spectrum of diseases, including hemorrhagic colitis and hemolytic uremic syndrome (HUS). Almost 5\% of STEC infections result from waterborne exposures, yet there is no test listed in the EPA's current Selected Analytical Methods for the detection of active Shiga toxins (Stxs) in water. In this study, a HeLa cell-based assay is validated for the detection of metabolically active Stxs produced by STEC in water, including tap, bottled, and pond water. Active Stxs are detected even when the number of Stx-producing bacteria is less than $0.4 \mathrm{CFU} / \mathrm{mL}$ and the assay performance is not affected by background flora or chlorine in the water. This assay is not only as simple and affordable as cell-free assays but also detects active holotoxins without the use of live animals. In addition, the assay is designed for use in multi-well formats, making it ideal for high-throughput screening of water samples and therefore useful for environmental public health surveillance programs to reduce human risk of infection with STEC.
\end{abstract}

Keywords: STEC; E. coli; waterborne; cytotoxicity; Shiga toxin; chlorine; HeLa cell

\section{Introduction}

From 2009 to 2017, 603 reported Shiga-toxin-producing Escherichia coli (STEC) outbreaks resulted in 7869 illnesses and 1404 hospitalizations [1]. Roughly 4.5\% of the reported STEC outbreaks during the 8-year period were a result of exposure to contaminated water [1]. There are many possible sources of waterborne STEC infections. Water mains can become exposed to STEC from damp soils near the site of repair or installation, whereas well water and aquifers can be contaminated by animal feces or sewage seepage [2-6]. Similarly, STEC can be found in recreational waters due to runoff or improper chlorination of pools [7,8]. Even bottled water is a potential source of infection, as O157:H7 has been shown to survive for up to 63 days in commercial bottled mineral water [9]. Nine $( \pm 5)$ waterborne STEC outbreaks are reported annually in the United States; however, it is thought that as few as $10 \%$ of the actual cases are reported and investigated. The actual number of outbreaks may be as much as $90 \%$ higher due to underreporting, detection limitations, and difficulties in tracking waterborne contaminants [1,2]. Thus, continued surveillance of E. coli contamination in drinking water is imperative for outbreak prevention.

STEC is capable of expressing a wide array of virulence factors, but Shiga toxins (Stxs) are the primary factor responsible for the development of severe complications like hemorrhagic colitis and hemolytic uremia syndrome [10-12]. Stxs are ribosomal inactivating proteins that can be divided into two serologically distinct groups: Stx1 (subtypes: Stx1a, Stx1c, Stx1d, and Stx1e) and Stx2 (Stx2 a-i, and Stx2k) [13-20]. STEC expressing Stx1a, Stx2a, Stx2c, or Stx2d are more often associated with human 
disease, but illnesses due to STEC expressing less common subtypes have been reported [21-24]. Stx subtypes vary in stability under extreme conditions and some can retain activity under conditions lethal to the organism, suggesting that consumption of products contaminated with active Stxs could result in illness even if the bacteria have been neutralized [25-27]. Because an effective therapeutic to treat $E$. coli infections does not exist, frequent water quality monitoring and continued improvement of STEC diagnostics are crucial.

Table 1 highlights a selection of methods for the detection of Shiga toxins. Each method has its advantages and disadvantages. In general, however, there is a tradeoff between the ability of an assay to detect toxin activity and the ability to differentiate Stx (sub)types. The methods recommended by the Environmental Protection Agency (EPA) in the Selected Analytical Methods (SAM) [28] for analyzing environmental water samples for Stxs can discriminate Stx types (ELISA) [29] and subtypes (LC-MS) [30] but cannot discriminate between active and inactive toxins [28]. The most common approaches that detect Stxs activity are mouse bioassays and cell-free assays [31,32]. Mouse bioassays are the gold standard for detection of active toxins but they can be technically challenging, require specific expertise and facilities, and are time-consuming. The cell-free assays are easier, fast, and cheaper but only detect the enzymatic activity of the A-subunit of Stxs. They do not monitor the activity of the holotoxins $[27,33,34]$. In contrast, cell-based cytotoxicity assays combine the benefits of the above two methods: they are rapid, inexpensive, and easy and detect the activity of the holotoxin.

Table 1. Common tests used for Stxs.

\begin{tabular}{|c|c|c|c|c|}
\hline Assay Type & Assay Time & LOD $^{a}$ & Detection Principle & Detects Activity \\
\hline ELISA [29] & $2.5 \mathrm{~h}$ & $25 \mathrm{pg} / \mathrm{mL}$ & $\mathrm{mAb}^{\mathrm{b}}$ capture, $\mathrm{mAb}$ detection & No \\
\hline LC-MS [30] & $5-6 \mathrm{~h}$ & $5 \mathrm{fmol} / \mathrm{mL}$ & $\begin{array}{l}\text { Conserved peptides (tryptic digestion } \\
\text { of the B subunits) }\end{array}$ & No \\
\hline Mouse bioassay [35] & 5 days & $290 \mathrm{ng} / \mathrm{kg}$ & Uses death rate to estimate $\operatorname{LD} 50^{\mathrm{c}}$ & Yes \\
\hline Cell-free translation [33] & $90 \mathrm{~min}$ & $20 \mathrm{pg} / \mathrm{mL}$ & Luciferase protein synthesis & Yes \\
\hline HeLa assay * & 2 days & $23 \mathrm{pg} / \mathrm{mL}$ & ATP assay for detection of viable cells & Yes \\
\hline
\end{tabular}

Here, we demonstrate a cell-based assay that is capable of detecting active Stxs in water samples spiked with as few as 0.4 colony-forming units (CFU)/mL of STEC. This cell-based assay eliminates the need for using live animals, allows high-throughput screening, and yields results in a short amount of time. In addition, the performance of the assay is not affected by either the presence of chlorine at the concentrations used to treat drinking water or the background flora present in environmental samples.

\section{Materials and Methods}

\subsection{Water Sample Collection}

Samples of bottled water, tap water, and pond water were acquired from local sources in Alameda County, California, and collected in sterile tubes. All samples were collected in duplicate at 2 separate times. Alameda County treats tap water with chlorine, ammonia, fluoride, and sodium hydroxide [36].

\subsection{Stx Enrichment and CFU Determination}

All strains used are listed in Table 2. 
Table 2. Strains used in this study.

\begin{tabular}{cccc}
\hline Organism & Strain & Stx Expressed & Reference/Collection \\
\hline E. coli & RM13506 & Stx1a & {$[37]$} \\
E. coli & RM10638 & Stx2a & {$[38]$} \\
E. coli & RM7370 & Stx1a and Stx2a & {$[39]$} \\
E. coli & ATCC25922 & n/a & ATCC $^{\circledR} 25922^{\mathrm{TM}}$ \\
Human & tGFP-HeLa (LINTERNA) & n/a & P20107 $^{\text {Hath }}$ \\
\hline
\end{tabular}

Single colonies of E. coli strains with or without stx $1 a$, stx $2 a$, or both stx $1 a$ and stx $2 a$ genes were inoculated into tryptone soya broth (TSB) and grown at $37^{\circ} \mathrm{C}$ for $18 \mathrm{~h}$. The overnight culture was then serially diluted into Bacto peptone water (BPW) to $10 \mathrm{CFU} / \mathrm{mL}$. Actual inoculum levels were later determined by spread-plating $0.1 \mathrm{~mL}$ of the cultures onto tryptone soya agar (TSA) plates and incubating them overnight at $37^{\circ} \mathrm{C}$ for manual colony counting. One $\mathrm{mL}$ of diluted culture in BPW was added to $24 \mathrm{~mL}$ of the water samples and enriched with $75 \mathrm{~mL}$ TSB containing $50 \mathrm{ng} / \mathrm{mL}$ mitomycin $\mathrm{C}$ (MMC) and $10 \mathrm{~g} / \mathrm{L}$ casamino acids, which was then grown at $42{ }^{\circ} \mathrm{C}$ for $16 \mathrm{~h}$. A $25 \mathrm{~mL}$ water-only control ("un-inoculated") was enriched using the same protocol as the inoculated samples. Following overnight enrichment, $500 \mu \mathrm{L}$ of each sample was lysed with an equal volume of phosphate B-PER reagent (ThermoFisher Scientific, Waltham, MA, USA) for $1 \mathrm{~h}$ at $37^{\circ} \mathrm{C}$ and centrifuged at $13,000 \times g$ for $10 \mathrm{~min}$ at $4{ }^{\circ} \mathrm{C}$. Bacterial supernatants were collected and filtered through a $0.2 \mu \mathrm{m}$ filter and used in cytotoxicity assays as described below (Figure 1).

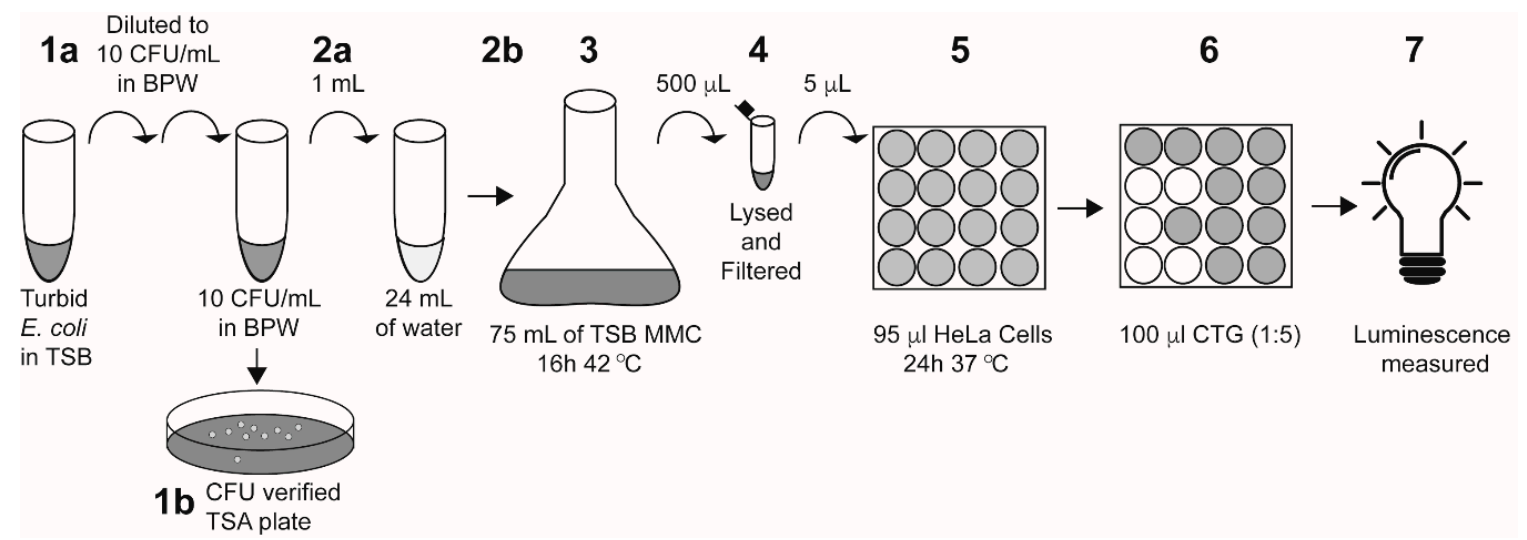

Figure 1. A schematic of the E. coli-inoculated water sample preparation and HeLa cell assay. Step 1a: a turbid overnight culture was serially diluted into BPW to $10 \mathrm{CFU} / \mathrm{mL}$. Step 1b: $100 \mu \mathrm{L}$ of the diluted culture was plated onto TSA plates to verify inoculum levels. Step 2a: $1 \mathrm{~mL}$ of the diluted $E$. coli culture was added to $24 \mathrm{~mL}$ of the indicated water sample. Step $2 \mathrm{~b}$ : the entire $25 \mathrm{~mL}$ water-E. coli mixture was added to $75 \mathrm{~mL}$ of TSB containing $50 \mathrm{ng} / \mathrm{mL}$ mitomycin C and $10 \mathrm{~g} / \mathrm{L}$ casamino acids. Note: for un-inoculated controls, $25 \mathrm{~mL}$ of the indicated water sample was added to the TSB without the $1 \mathrm{~mL}$ of E. coli. Step 3: Culture was enriched at $42{ }^{\circ} \mathrm{C}$ for $16 \mathrm{~h}$. Step 4: $500 \mu \mathrm{L}$ of the enriched sample was lysed with the addition of $500 \mu \mathrm{L}$ of B-PER reagent, then filter-sterilized. Step 5: The enriched filtered lysate $(5 \mu \mathrm{L})$ was added directly to $95 \mu \mathrm{L}$ of HeLa cells in a 96-well plate and incubated at $37^{\circ} \mathrm{C}$ for $24 \mathrm{~h}$ with 5\% $\mathrm{CO}_{2}$. Step 6: $100 \mu \mathrm{L}$ of Cell-Titer Glo (CTG) reagent was added to each well. Step 7: Luminescence was measured on a plate reader.

\subsection{Stx2a Protein Purification}

Stx2a was purified from MMC-induced E. coli supernatants (RM10638) by affinity chromatography using an affinity column (Thermo Scientific AminoLink Plus Immobilization Kit, Waltham, MA, USA) coupled to mAb Stx2-1, which binds the A-subunit, and mAb Stx2-5, which binds both the A- and B-subunits, followed by gel filtration on an AKTA FPLC using a Superdex 200-XK 26/70 column (GE Healthcare, Marlborough, MA, USA) as described previously [40]. 


\subsection{Cytotoxicity Assays}

Stxs cytotoxicity was determined using a microtiter HeLa cell assay [38]. A 96-well plate (Corning) was seeded with $10^{4}$ Linterna tGFP HeLa cells (InnoProt, Spain) in high-glucose Dulbecco's Modified Eagle Medium (DMEM) supplemented with 1× Glutamax, $250 \mu \mathrm{g} / \mathrm{mL}$ G418 and 10\% fetal bovine serum (FBS). Plated HeLa cells were treated with the indicated Stx condition (see below) and incubated for $24 \mathrm{~h}$ at $37^{\circ} \mathrm{C}$ and $5 \% \mathrm{CO}_{2}$.

Following Stx treatment, cytotoxicity was assessed by the addition of Cell-Titer Glo (CTG, Promega, Madison, WI, USA) according to the manufacturer's instructions, with the exception of diluting the reagent 1:5 in Phosphate-Buffered Saline (PBS) (Figure 1). Luminescence was measured for $0.1 \mathrm{~s}$ in a VictorIII plate reader (Perkin Elmer, Waltham, MA, USA). Luminescence measurements were used to calculate percent survival and percent cytotoxicity as described below. All conditions were assayed in triplicate and repeated twice.

\subsection{1. $\mathrm{CD}_{50}$}

The concentration of Stx 2 a required to reach $50 \%$ of cell death $\left(\mathrm{CD}_{50}\right)$ was determined by incubating HeLa cells with 10-fold serial dilutions of pure Stx2a from $10 \mathrm{fg} / \mathrm{mL}$ to $100 \mathrm{ng} / \mathrm{mL}$ in DMEM for $24 \mathrm{~h}$ at $37^{\circ} \mathrm{C}$ with $5 \% \mathrm{CO}_{2}$. Percent survival was calculated as: (counts per second (CPS) of the experimental sample/average CPS DMEM-only control) $\times 100 \%$ and plotted on a semi-log scale. The linear portion of the dose response curve was used to estimate the concentration of Stx2a needed to reach $C D_{50}$.

\subsubsection{Water}

To determine cytotoxicity of Stxs in water samples, $5 \mu \mathrm{L}$ of the enriched samples was added to HeLa cells and incubated for $24 \mathrm{~h}$ at $37^{\circ} \mathrm{C}$ with $5 \% \mathrm{CO}_{2}$ in 96-well plates. The percent toxicity was calculated as (the average CPS of the DMEM-only control - the CPS of the experimental sample)/average DMEM control $\times 100 \%$.

\subsubsection{Chlorine}

The effect of chlorine on HeLa cell viability was assessed by preparing 2-fold dilutions of sodium hypochlorite (bleach) from $0.2-3.2 \mathrm{mg} / \mathrm{L}$ in sterile water. The diluted chlorine $(5 \mu \mathrm{L})$ was then added to $10^{4} \mathrm{HeLa}$ cells in DMEM and incubated for $24 \mathrm{~h}$ at $37^{\circ} \mathrm{C}$ with $5 \% \mathrm{CO}_{2}$.

\section{Results and Discussion}

The EPA's current Selected Analytical Methods (SAM) recommended for Stx detection in environmental samples do not include a method that differentiates between active and inactive toxins. Therefore, we wanted to determine if a cell-based assay is appropriate for detection of active Stxs present in environmental water samples. First, we tested the cytotoxic effect of Stx2a on the human cell line available in our lab. A dose response was observed when Stx2a was diluted 10-fold between $100 \mathrm{fg} / \mathrm{mL}$ and $100 \mathrm{pg} / \mathrm{mL}$ in a 96-well microtiter plate seeded with $10^{4} \mathrm{HeLa}$ cells. A CD 50 (the toxin concentration that kills $50 \%$ of cells) of $23.38 \mathrm{pg} / \mathrm{mL} \pm 0.6$ was observed (Figure 2). To confirm that Stx2a was responsible for the cytotoxicity, a neutralization test was performed by pre-incubating Stxs with Stx2-specific $\mathrm{mAb}$ prior to incubation in the human cells. Consistent with previously reported results, the addition of Stx2a mAb neutralized the cytotoxicity of Stx2a to the HeLa cells (data not shown), confirming the specificity of the assay [38]. We note that the $\mathrm{CD}_{50}$ reported here is lower than previously reported and thus appears to be more sensitive to Stx2a [38]. The difference is likely due to the use of different cell lines (GFP expression) or slight differences in toxin preparation due to inter-researcher variability and further highlights how comparisons of absolute toxicity across studies are not valid [25]. Nevertheless, we reconfirm that HeLa cells can be used to detect pure active Stx and emphasize the importance of standardized controls within and between experiments. 


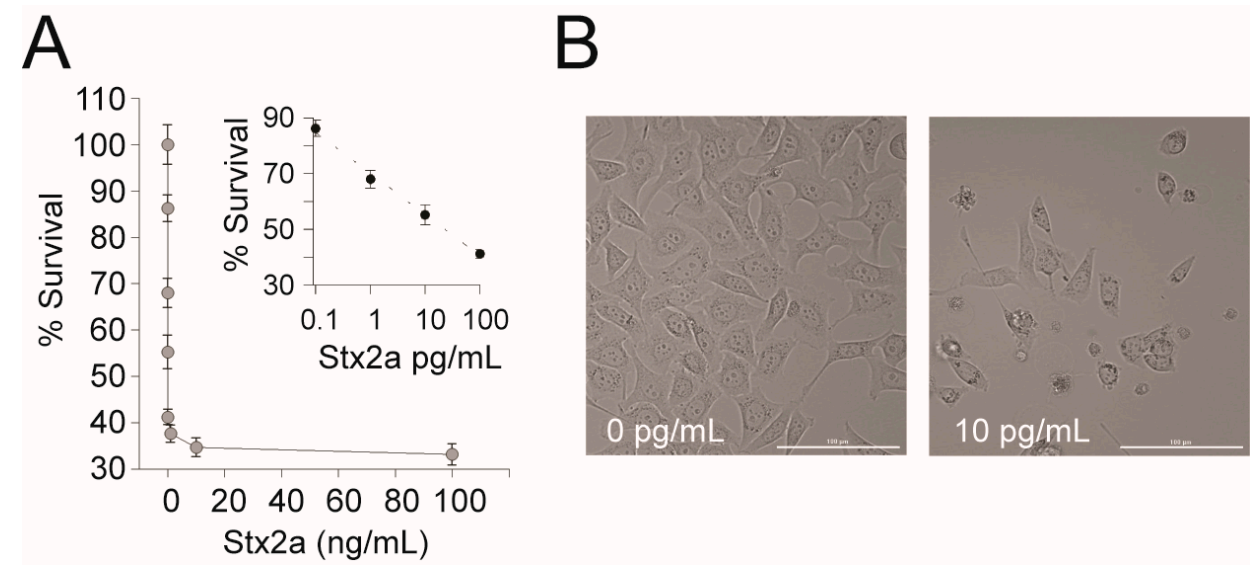

Figure 2. HeLa cell assay for Stx2a activity. (A) A representative dose response curve of Stx2a-treated HeLa cells. HeLa cells were treated with 10 -fold serial dilutions of Stx2a from $10 \mathrm{fg} / \mathrm{mL}$ to $100 \mathrm{ng} / \mathrm{mL}$ in DMEM for $24 \mathrm{~h}$ at $37{ }^{\circ} \mathrm{C}$ with $5 \% \mathrm{CO}_{2}$. Cell viability was measured using Cell Titer Glo and luminescence was measured on a Victor3 plate reader. Percent survival was calculated as (CPS of the experimental well/CPS of the DMEM only control $) \times 100 \%$. Inset: The linear portion of the semi-log transformed curve. The dashed line is the best-fit equation used to calculate the $\mathrm{CD}_{50}(y=-6.425$ $\ln (x)+70), R^{2}=0.99$. Error bars represent the standard deviation of the mean from three replicates. (B) Representative images (20× magnification) of HeLa cells intoxicated with Stx2a or a medium-only control. Scale bar is $100 \mu \mathrm{m}$.

Cell culture assays are notoriously sensitive to changes in growth conditions and there are various components present in different water sources with the potential to introduce assay variability [41-44]. Therefore, various water sources (bottled, tap, and pond water) were tested for their effect on HeLa cell growth. First, the background flora present in samples was determined via total aerobic plate counting. No microbial growth was detected in bottled or tap water samples. The background level detected in pond water was $5 \times 10^{2} \mathrm{CFU} / \mathrm{mL}$ but did not appear to affect the HeLa cell assay compared with the bottled and tap water samples (Table 3). Moreover, none of the drinking water sources had an effect on HeLa cell viability compared with the negative control (Table 3).

Table 3. Detection of Stx cytotoxicity in water samples inoculated with bacteria.

\begin{tabular}{ccccc}
\hline Bacterial Strain * & No. Sample Control & Bottled Water & Tap Water & Pond Water \\
\hline Un-inoculated & $106,790 \pm 2319(0 \%)$ & $112,485 \pm 4136(-5 \%)$ & $111,440 \pm 509(-4 \%)$ & $119,550 \pm 1145(-12 \%)$ \\
RM13506-Stx1a & & $25,190 \pm 791(76 \%)$ & $28,230 \pm 197(74 \%)$ & $28,310 \pm 1357(73 \%)$ \\
RM10638-Stx2a & & $35,900 \pm 9687(66 \%)$ & $34,895 \pm 431(67 \%)$ & $32,710 \pm 395(69 \%)$ \\
RM7370-Stx1a/2a & $30,945 \pm 2962(71 \%)$ & $39,810 \pm 565(63 \%)$ & $36,735 \pm 2849(66 \%)$ \\
ATCC25922-no Stx & & $106,225 \pm 926(1 \%)$ & $111,035 \pm 487(-4 \%)$ & $112,725 \pm 3146(-6 \%)$ \\
\hline
\end{tabular}

Data represent counts per second \pm standard deviation (cytotoxic dose). ${ }^{*}$ The predicted inoculum level of each strain was $0.4 \mathrm{CFU} / \mathrm{mL}$; the actual inoculum levels ranged from 0.24 to $0.48 \mathrm{CFU} / \mathrm{mL}$.

The EPA allows up to $4 \mathrm{mg} / \mathrm{L}$ of chlorine $(\mathrm{NaOCl})$ as a drinking water disinfectant; however, it was unknown if HeLa cell performance is affected by chlorine [45]. To assess HeLa cell viability in the presence of the chlorine specifically, the disinfectant was serially two-fold diluted into pure water from 0 to $3.2 \mathrm{mg} / \mathrm{L}$ and $5 \mu \mathrm{L}$ was added to $10^{4} \mathrm{HeLa}$ cells. After an overnight incubation with the chlorinated water, HeLa cells remained viable across all concentrations tested (Figure 3). This suggests that HeLa cell performance would not be affected by the presence of chlorine when used to assay for biologically active Stxs in chlorinated water. 


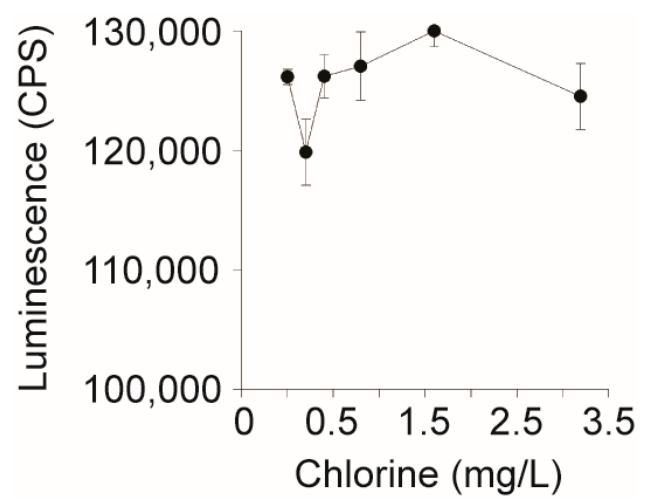

Figure 3. Effect of chlorine levels on the performance of the HeLa cell-based assay. Sodium hypochlorite (bleach) was diluted two-fold from 3.2 to $0.2 \mathrm{mg} / \mathrm{L}$ and $5 \mu \mathrm{L}$ was added to $10^{4} \mathrm{HeLa}$ cells in DMEM, which were incubated for $24 \mathrm{~h}$ at $37^{\circ} \mathrm{C}$ with $\mathrm{CO}_{2}$. Cell viability was measured using Cell Titer Glo and luminescence was measured on a Victor3 plate reader.

STEC infections are characterized by an extremely low human infectious dose: fewer than 10 cells are sufficient to cause illness [46]. To validate the capability of the HeLa cell assay for the detection of live STEC present in environmental water samples using Stx as a marker, water samples, including bottled, tap, and pond water, were spiked with a low infectious dose (6-12 CFU/25 mL) of st $x$-positive and negative strains. Table 3 demonstrates that water samples inoculated with STEC producing Stx1a, Stx $2 a$, or both Stx1a/2a exhibited $63-76 \%$ cytotoxicity, whereas less than $1 \%$ toxicity was detected in un-inoculated samples or samples inoculated with a non-STEC strain. No significant differences $(p>0.05)$ in cytotoxicity were detected in samples (bottled, tap, and pond water) inoculated with the same STEC strains (Table 3), suggesting there were no matrix effects associated with these samples. These results indicate that the HeLa cell assay could detect STEC in water unambiguously. Relative to other activity assays, this assay is simple, sensitive, and reliable and would complement the current Stx assays recommended by the EPA.

\section{Conclusions}

The Stx enrichment and HeLa cell cytotoxicity assay developed here detects enzymatically active holo-Stxs produced at less than $0.4 \mathrm{CFU} / \mathrm{mL}$ of STEC in water. Common water additives, such as chlorine and fluoride, or background flora present in water do not appear to interfere with the assay or cause any growth competition for the relatively low inoculum levels of STEC targeted. This HeLa cell cytotoxicity assay holds promise for the identification of live STEC present in environmental water by food industries, the EPA, or other regulators.

Author Contributions: Conceptualization, X.H. and R.R.; methodology, A.C.H. and S.P.; validation, A.C.H. and S.P.; formal analysis, X.H., A.C.H., and S.P.; investigation, A.C.H. and S.P.; resources, R.R.; data curation, A.C.H. and S.P.; writing-original draft preparation, A.C.H. and S.P.; writing—review and editing, X.H.; supervision, X.H. All authors have read and agreed to the published version of the manuscript.

Funding: This research received no external funding.

Conflicts of Interest: The authors declare no conflict of interest.

\section{References}

1. Centers for Disease Control and Prevention (CDC). National Outbreak Reporting System Dashboard. Atlanta, Georgia: U.S. Department of Health and Human Services, CDC. Available online: wwwn.cdc.gov/ norsdashboard (accessed on 5 August 2020).

2. Craun, G.F.; Calderon, R.L.; Craun, M.F. Waterborne Disease Outbreaks: Their Causes, Problems, and Challenges to Treatment Barriers; American Water Works Association: Denver, CO, USA, 2006. 
3. Swerdlow, D.L.; Woodruff, B.A.; Brady, R.C.; Griffin, P.M.; Tippen, S.; Donnell, H.D., Jr.; Geldreich, E.; Payne, B.J.; Meyer, A., Jr.; Wells, J.G.; et al. A waterborne outbreak in Missouri of Escherichia coli O157:H7 associated with bloody diarrhea and death. Ann. Intern. Med. 1992, 117, 812-819. [CrossRef]

4. Haas, C.N.; Gupta, M.; Burlingame, G.A.; Chitluru, R.B.; Pipes, W.O. Bacterial levels of new mains. J. Am. Water Works Assoc. 1999, 91, 78-84. [CrossRef]

5. Olsen, S.J.; Miller, G.; Breuer, T.; Kennedy, M.; Higgins, C.; Walford, J.; McKee, G.; Fox, K.; Bibb, W.; Mead, P. A waterborne outbreak of Escherichia coli O157:H7 infections and hemolytic uremic syndrome: Implications for rural water systems. Emerg. Infect. Dis. 2002, 8, 370-375. [CrossRef] [PubMed]

6. Centers for Disease Control and Prevention (CDC). Public Health Dispatch: Outbreak of Escherichia coli O157:H7 and Campylobacter Among Attendees of the Washington County Fair-New York, 1999. MMWR 1999, 48, 803-805.

7. Fincher, L.M.; Parker, C.D.; Chauret, C.P. Occurrence and antibiotic resistance of Escherichia coli O157:H7 in a watershed in north-central Indiana. J. Environ. Qual. 2009, 38, 997-1004. [CrossRef] [PubMed]

8. Friedman, M.S.; Roels, T.; Koehler, J.E.; Feldman, L.; Bibb, W.F.; Blake, P. Escherichia coli O157:H7 outbreak associated with an improperly chlorinated swimming pool. Clin. Infect. Dis. 1999, 29, 298-303. [CrossRef]

9. Kerr, M.; Fitzgerald, M.; Sheridan, J.J.; McDowell, D.A.; Blair, I.S. Survival of Escherichia coli O157:H7 in bottled natural mineral water. J. Appl. Microbiol. 1999, 87, 833-841. [CrossRef]

10. Siegler, R.L. Postdiarrheal Shiga toxin-mediated hemolytic uremic syndrome. JAMA 2003, 290, $1379-1381$. [CrossRef]

11. Friedrich, A.W.; Bielaszewska, M.; Zhang, W.L.; Pulz, M.; Kuczius, T.; Ammon, A.; Karch, H. Escherichia coli harboring Shiga toxin 2 gene variants: Frequency and association with clinical symptoms. J. Infect. Dis. 2002, 185, 74-84. [CrossRef]

12. Russmann, H.; Schmidt, H.; Heesemann, J.; Caprioli, A.; Karch, H. Variants of Shiga-like toxin II constitute a major toxin component in Escherichia coli O157 strains from patients with haemolytic uraemic syndrome. J. Med. Microbiol. 1994, 40, 338-343. [CrossRef]

13. Strockbine, N.A.; Marques, L.R.; Newland, J.W.; Smith, H.W.; Holmes, R.K.; O’Brien, A.D. Two toxin-converting phages from Escherichia coli O157:H7 strain 933 encode antigenically distinct toxins with similar biologic activities. Infect. Immun. 1986, 53, 135-140. [CrossRef] [PubMed]

14. Head, S.C.; Karmali, M.A.; Lingwood, C.A. Preparation of Vt1 and Vt2 Hybrid Toxins from Their Purified Dissociated Subunits_Evidence for B-Subunit Modulation of a Subunit Function. J. Biol. Chem. 1991, 266, 3617-3621. [PubMed]

15. Scheutz, F.; Teel, L.D.; Beutin, L.; Pierard, D.; Buvens, G.; Karch, H.; Mellmann, A.; Caprioli, A.; Tozzoli, R.; Morabito, S.; et al. Multicenter evaluation of a sequence-based protocol for subtyping Shiga toxins and standardizing Stx nomenclature. J. Clin. Microbiol. 2012, 50, 2951-2963. [CrossRef] [PubMed]

16. Lacher, D.W.; Gangiredla, J.; Patel, I.; Elkins, C.A.; Feng, P.C. Use of the Escherichia coli Identification Microarray for Characterizing the Health Risks of Shiga Toxin-Producing Escherichia coli Isolated from Foods. J. Food Prot. 2016, 79, 1656-1662. [CrossRef]

17. Bai, X.N.; Fu, S.S.; Zhang, J.; Fan, R.Y.; Xu, Y.M.; Sun, H.; He, X.H.; Xu, J.G.; Xiong, Y.W. Identification and pathogenomic analysis of an Escherichia coli strain producing a novel Shiga toxin 2 subtype. Sci. Rep. 2018, 8 , 1-11. [CrossRef]

18. Yang, X.; Bai, X.; Zhang, J.; Sun, H.; Fu, S.; Fan, R.; He, X.; Scheutz, F.; Matussek, A.; Xiong, Y. Escherichia coli strains producing a novel Shiga toxin 2 subtype circulate in China. Int. J. Med. Microbiol. 2020, 310, 151377. [CrossRef]

19. Di, R.; Kyu, E.; Shete, V.; Saidasan, H.; Kahn, P.C.; Tumer, N.E. Identification of amino acids critical for the cytotoxicity of Shiga toxin 1 and 2 in Saccharomyces Cerevisiae. Toxicon 2011, 57, 525-539. [CrossRef]

20. Endo, Y.; Tsurugi, K.; Yutsudo, T.; Takeda, Y.; Ogasawara, T.; Igarashi, K. Site of action of a Vero toxin (VT2) from Escherichia coli O157:H7 and of Shiga toxin on eukaryotic ribosomes. RNA N-glycosidase activity of the toxins. Eur. J. Biochem. 1988, 171, 45-50. [CrossRef]

21. Luna-Gierke, R.E.; Griffin, P.M.; Gould, L.H.; Herman, K.; Bopp, C.A.; Strockbine, N.; Mody, R.K. Outbreaks of non-O157 Shiga toxin-producing Escherichia coli infection: USA. Epidemiol. Infect. 2014, 142, 2270-2280. [CrossRef] 
22. Beutin, L.; Krause, G.; Zimmermann, S.; Kaulfuss, S.; Gleier, K. Characterization of Shiga Toxin-Producing Escherichia coli Strains Isolated from Human Patients in Germany over a 3-Year Period. J. Clin. Microbiol. 2004, 42, 1099. [CrossRef]

23. Fasel, D.; Mellmann, A.; Cernela, N.; Hachler, H.; Fruth, A.; Khanna, N.; Egli, A.; Beckmann, C.; Hirsch, H.H.; Goldenberger, D.; et al. Hemolytic uremic syndrome in a 65-Year-old male linked to a very unusual type of stx2e- and eae-harboring O51:H49 shiga toxin-producing Escherichia coli. J. Clin. Microbiol. 2014, 52, 1301-1303. [CrossRef] [PubMed]

24. Friesema, I.; van der Zwaluw, K.; Schuurman, T.; Kooistra-Smid, M.; Franz, E.; van Duynhoven, Y.; van Pelt, W. Emergence of Escherichia coli encoding Shiga toxin $2 \mathrm{f}$ in human Shiga toxin-producing E. coli (STEC) infections in the Netherlands, January 2008 to December 2011. Eurosurveillance 2014, 19, $26-32$. [CrossRef] [PubMed]

25. Skinner, C.; McMahon, S.; Rasooly, R.; Carter, J.M.; He, X. Purification and characterization of Shiga toxin 2f, an immunologically unrelated subtype of Shiga toxin 2. PLoS ONE 2013, 8, e59760. [CrossRef] [PubMed]

26. Hughes, A.C.; Zhang, Y.Z.; Bai, X.N.; Xiong, Y.W.; Wang, Y.; Yang, X.; Xu, Q.P.; He, X.H. Structural and Functional Characterization of Stx2k, a New Subtype of Shiga Toxin 2. Microorganisms 2020, 8, 4. [CrossRef]

27. Tesh, V.L.; Burris, J.A.; Owens, J.W.; Gordon, V.M.; Wadolkowski, E.A.; O’Brien, A.D.; Samuel, J.E. Comparison of the relative toxicities of Shiga-like toxins type I and type II for mice. Infect. Immun. 1993, 61, 3392-3402. [CrossRef]

28. U.S. Environmental Protection Agency (U.S. EPA). Selected Analytical Methods for Environmental Remediation and Recovery (SAM) 2012; EPA/600/R-12/555; U.S. Environmental Protection Agency: Washington, DC, USA, 2012.

29. Kong, Q.; Patfield, S.; Skinner, C.; Stanker, L.H.; Gehring, A.G.; Fratamico, P.; Rubio, F.M.; Qi, W.; $\mathrm{He}, \mathrm{X}$. Validation of Two New Immunoassays for Sensitive Detection of a Broad Range of Shiga Toxins. Austin Immunol. 2016, 1, 1007.

30. Silva, C.J.; Erickson-Beltran, M.L.; Skinner, C.B.; Dynin, I.; Hui, C.; Patfield, S.A.; Carter, J.M.; He, X. Safe and effective means of detecting and quantitating Shiga-like toxins in attomole amounts. Anal. Chem. 2014, 86, 4698-4706. [CrossRef]

31. Hale, M.L. Microtiter-based assay for evaluating the biological activity of ribosome-inactivating proteins. Pharmacol. Toxicol. 2001, 88, 255-260. [CrossRef]

32. Zhan, J.; Zhou, P. A simplified method to evaluate the acute toxicity of ricin and ricinus agglutinin. Toxicology 2003, 186, 119-123. [CrossRef]

33. He, X.; Quinones, B.; Carter, J.M.; Mandrell, R.E. Validation of a cell-free translation assay for detecting shiga toxin 2 in bacterial culture. J. Agric. Food Chem. 2009, 57, 5084-5088. [CrossRef]

34. Russo, L.M.; Melton-Celsa, A.R.; Smith, M.A.; Smith, M.J.; Brien, A.D. Oral Intoxication of Mice with Shiga Toxin Type 2a (Stx2a) and Protection by Anti-Stx2a Monoclonal Antibody 11E10. Infect. Immun. 2014, 82, 1213. [CrossRef]

35. Cheng, L.W.; Henderson, T.D.; Patfield, S.; Stanker, L.H.; He, X.H. Mouse in Vivo Neutralization of Escherichia coli Shiga Toxin 2 with Monoclonal Antibodies. Toxins 2013, 5, 1845-1858. [CrossRef] [PubMed]

36. ACWD Alameda Coutnry Water Distrcit. Available online: https://www.acwd.org/101/Treatment-PlantDescriptions (accessed on 11 August 2020).

37. He, X.; Patfield, S.; Hnasko, R.; Rasooly, R.; Mandrell, R.E. A polyclonal antibody based immunoassay detects seven subtypes of Shiga toxin 2 produced by Escherichia coli in human and environmental samples. PLOS ONE 2013, 8, e76368. [CrossRef]

38. He, X.; Quinones, B.; McMahon, S.; Mandrell, R.E. A single-step purification and molecular characterization of functional Shiga toxin 2 variants from pathogenic Escherichia coli. Toxins 2012, 4, 487-504. [CrossRef]

39. Diodati, M.E.; Bates, A.H.; Cooley, M.B.; Walker, S.; Mandrell, R.E.; Brandl, M.T. High Genotypic and Phenotypic Similarity Among Shiga Toxin-Producing Escherichia coli O111 Environmental and Outbreak Strains. Foodborne Pathog. Dis. 2015, 12, 235-243. [CrossRef]

40. He, X.; Qi, W.; Quiñones, B.; McMahon, S.; Cooley, M.; Mandrell, R.E. Sensitive Detection of Shiga Toxin 2 and Some of Its Variants in Environmental Samples by a Novel Immuno-PCR Assay. Appl. Environ. Microb. 2011, 77, 3558. [CrossRef] [PubMed]

41. Leist, C.H.; Meyer, H.P.; Fiechter, A. Potential and problems of animal cells in suspension culture. J. Biotechnol. 1990, 15, 1-46. [CrossRef] 
42. Vierck, J.L.; Dodson, M.V. Interpretation of cell culture phenomena. Methods Cell Sci. 2000, $22,79-81$. [CrossRef] [PubMed]

43. Geraghty, R.J.; Capes-Davis, A.; Davis, J.M.; Downward, J.; Freshney, R.I.; Knezevic, I.; Lovell-Badge, R.; Masters, J.R.; Meredith, J.; Stacey, G.N.; et al. Guidelines for the use of cell lines in biomedical research. Br. J. Cancer 2014, 111, 1021-1046. [CrossRef]

44. Phelan, K.; May, K.M. Basic Techniques in Mammalian Cell Tissue Culture. Curr. Protoc. Toxicol. 2016, 70, A 3B 1-A 3B 22. [CrossRef]

45. Ground Water and Drinking Water. National Primary Drinking Water Regulations. Available online: https: //www.epa.gov/ground-water-and-drinking-water/national-primary-drinking-water-regulations (accessed on 26 August 2020).

46. Willshaw, G.A.; Thirlwell, J.; Jones, A.P.; Parry, S.; Salmon, R.L.; Hickey, M. Vero cytotoxin-producing Escherichia coli O157 in beefburgers linked to an outbreak of diarrhoea, haemorrhagic colitis and haemolytic uraemic syndrome in Britain. Lett. Appl. Microbiol. 1994, 19, 304-307. [CrossRef]

Publisher's Note: MDPI stays neutral with regard to jurisdictional claims in published maps and institutional affiliations.

(C) 2020 by the authors. Licensee MDPI, Basel, Switzerland. This article is an open access article distributed under the terms and conditions of the Creative Commons Attribution (CC BY) license (http://creativecommons.org/licenses/by/4.0/). 